\title{
Birth order, suckling behaviour and growth in piglets: A case study of the extreme delay in birth of two surviving piglets
}

\author{
Ana LONČARIČ, Maja PREVOLNIK POVŠE*, Janko SKOK, Dejan ŠKORJANC \\ Faculty of Agriculture and Life Sciences, Pivola 10, 2311 Hoče, Slovenia
}

\begin{abstract}
In pigs, higher birth order is associated with higher mortality rate, with abnormal delays in birth as a rule result in a prenatal death. Here we present a case study of an extreme delay in birth of two surviving piglets (delayed piglets) which were born $15 \mathrm{~h}$ after the beginning of parturition and $12 \mathrm{~h}$ after the last piglet of the main episode of the parturition $(\mathrm{n}=12)$ was born. The rest of the observed litter was divided into early born ( $n=6$, born within $80 \mathrm{~min}$ ) and late born piglets $(\mathrm{n}=6$, born within the next $80 \mathrm{~min}$ from the beginning of parturition). Suckling behaviour, survival and growth performance of piglets were studied in relation to birth order whereby special attention was given to the delayed piglets. In general, suckling stability tended to decrease with birth order with the delayed piglets having completely unstable suckling. In the first suckling, piglets predominantly chose posterior teats, but later, when suckling order was established, early born piglets preferentially sucked on the front half and the late born piglets on the back half of the udder. The delayed piglets suckled on the middle teats immediately after birth, but later they chose preferential teats on different parts of udder $\left(2^{\text {nd }}\right.$ and $6^{\text {th }}$ teat pair). Growth performance of delayed piglets was lower, although not significantly (probably due to small sample size), compared to the late and especially to the early born group. Despite an extraordinarily long delay in birth, there was no clear association with the suckling order and its stability, the birth/body weight and daily gain. However, survival of piglets after that long delay in birth itself represents an extraordinary phenomenon that we cannot explain.
\end{abstract}

Key words: birth order, suckling behaviour, growth performance, delay in birth

\section{INTRODUCTION}

Successful farrowing is defined when the duration of parturition does not exceed 5 hours and when all piglets receive colostrum (Peltoniemi and Oliviero, 2011). Farrowing is divided into three phases: opening, expulsion and postnatal stage (Blim et al., 2020). Sows farrowing usually lasts for several hours ( $\sim 3.5$ on average), with birth interval between two sequential piglets most often lasting for 20 to 30 minutes (but also up to 90 minutes); as a result, the interval between the first and the last born piglet could reach up to eight hours or even more (Canario et al., 2006; Oliviero et al., 2010). The prolongation of farrowing is normally influenced by the sows inability to move (Oliviero et al., 2010), the specific stress situation that inhibit normal secretion of oxytocin (Nagel et al., 2019), poor sow's body condition or some subclinical heath disorders (e.g. hypocalcaemia; Ayliffe et al., 1984). Either way, during these several hours long period, intrauterine (inside sow's body) and extrauterine (environmental) conditions can change to a great extent. Later born piglets are exposed to greater amount of postpartum convulsions and more often suffer from hypoxia (Randal, 1972; Herpin et al., 1996). As the parturition progressesalso theintensity of competition for teats increases. Besides, the sow does not develop any attachement 
to the piglets/litter and also does not help or lead the piglet immediately after birth to reach their teats faster (Nowak et al., 2000). Furthermore, there are known rapid changes in colostrum composition during first few hours after the onset of parturition especially in the content of immunoglobulins, which undergo rapid decline in the first 12 hours postpartum (Klobasa et al., 1987; Markowska-Daniel et al., 2010; Klobasa et al., 2004; Le Dividich et al., 2017), but also the amount of lipids, lactose and crude protein (Le Dividich et al., 2005), and other bioactive compounds (such as growth factors and cytokines; Rooke and Bland, 2002). Moreover, colostrum also plays an important role for piglets thermoregulation (Herpin et al., 2002). Although delaying suckling by up to 24 hours has no effect on the amount of colostrum ingested, the immunoglobulins concentration in colostrum is at that time significantly decreased (Bland et al., 2003), as well as the ingestion of colostrum triggers mechanisms in the intestinal wall that close the passage of large molecules (Rooke and Bland, 2002). All these factors, more or less directly related to the birth order, presumably have consequences, which are until now not fully understood. It has been proved that there is a higher prenatal mortality rate of late born piglets (Tuchscherer et al., 2000; Pedersen et al., 2011; Rootwelt et al., 2012; Panzardi et al., 2013); however, findings on the effect on growth performance are contradictory (Friend and Cunningham, 1966; Hartsock and Graves, 1976; Beaulieu et al., 2010; Charneca et al., 2013; Le Dividich et al., 2017; Slegers et al., 2021). Further, due to the challenging nature of such observations, research of the effect of birth order on suckling behaviour and animal welfare is scarce (e.g. Rosillon-Warnier and Paquay, 1984). Therefore, we aimed to highlight those relations between birth order, suckling behaviour (stability, preference), and growth performance of piglets based on the single but extraordinary case of piglets born alive but with an extreme delay. Here the partial results are presented based on the observation of only one sow with the litter in which two piglets were born with abnormal delay of 12 hours after the last piglet of the main episode of the parturition (i.e. 15 hours after first born piglet; more details in the section Materials and methods). Reported extreme case can provide exceptional insight into the association of birth order to the suckling behaviour and growth performance, compared to the rest of the litter born following normal birth interval. The case of two delayed piglets is therefore particularly exposed in the present short note.

\section{MATERIAL AND METHODS}

\section{Pens and animals}

The study was conducted at a small scale family farm in accordance with the national legislation on animal protection (UL RS 38/2013). One third-parity sow (Swedish Landrace $\times$ Large White) with its litter of 14 piglets ( 8 females, 6 males) was included in the study. The farrowing pen area was $6.4 \mathrm{~m}^{2}$ $(2.2 \mathrm{~m} \times 2.9 \mathrm{~m})$. The crate had solid wooden sidewalls. Pen flooring was partly slatted ( $\sim 1 / 3$, plastic lattices) and partially solid and covered with $5 \mathrm{~cm}$ straw bedding, which was of good quality, daily checked and replaced. Male piglets were castrated on the $3^{\text {rd }}$ day after birth. From the $4^{\text {th }}$ day of age piglets had the access to additional solid feed (pre-starter).

\section{Farrowing}

During the experiment, the observed sow was in a good body condition. The sow was transferred to the farrowing pen seven days before expected date of parturition and was left free to perform a specific behaviour. Three days before expected farrowing, the sow was confined into the crate. During these 7 days, the observer entered the pen 3-times per day for 10-15 minutes to get the sow used to the human presence, which was necessary to mitigate stress both, in the piglet labelling during the farrowing, and in the spoton observations conducted later. The farrowing took place in the evening hours. The observer followed farrowing and suckling by direct observations. The time of birth as well as the time and position (teat) of the first suckling was recorded. All piglets were born alive; however, two of them born $5^{\text {th }}$ and $6^{\text {th }}$ in a birth order, died during the experiment (on $5^{\text {th }}$ and $15^{\text {th }}$ day of lactation). The farrowing lasted from 7 to 10 p.m. The last two piglets were born only the next day at 10 a.m. (i.e., with 12 hours delay). Each born piglet was marked on its back with sequential number (1 to 14 ) according to birth order - piglets were then remarked when necessary to maintain individual traceability. For further analysis, the piglets were divided into three birth order groups: early born ( $1^{\text {st }}-6^{\text {th }}$ piglet, born within 80 minutes of the parturition), late born $\left(7^{\text {th }}-12^{\text {th }}\right.$ piglet, born within the next 80 minutes of the parturition) and delayed ( $13^{\text {th }}-14^{\text {th }}$ piglet, born 12 hours after the last piglets of the main episode of the parturition).

\section{Growth performance}

Piglets were weighed three times during lactation (Day 1,15 , and 30). Daily gain was calculated for three periods based on obtained body weight: Day 1-15, Day 15-30 and Day 1-30.

\section{Suckling behaviour}

The suckling position was registered for the first suckling and for the days 1, 15 and 30 of lactation where eight suckling sessions were monitored per day (four in the morning, four in the afternoon). The position of a single piglet was recorded when it has settled on the teat (pair), thus, in the milk letdown phase of a given suckling session. Teats were marked sequentially from cranial towards caudal part with numbers 1-16 (odd numbers for left side, even numbers for right side). Obtained data were used to calculate suckling stability $\left(p_{\text {suck }}\right)$ :

$$
\text { Psuck }=\frac{\left(\sum_{i=1} \text { to TP } n i(n i-1)\right)}{N(N-1)}
$$

where $n$ is the number of sucklings on a given suckling pair performed by a given piglet and $\mathrm{N}$ is the total number of 
sucklings observed on a given suckling pair. Suckling stability can range from 0 (complete instability; no piglet in the litter sucked more than once on a given teat) to 1 (complete stability; a particular suckling pair was used for only one piglet) (Skok and Škorjanc, 2013). For further analysis, three suckling areas were distinguished according to the suckling position (as described in Skok in Škorjanc, 2013): anterior ( $1^{\text {st }}$ and $2^{\text {nd }}$ teat pair), middle ( $3^{\text {th }}$ to $5^{\text {th }}$ teat pair) and posterior ( $6^{\text {th }}$ to $8^{\text {th }}$ teat pair).

\section{Statistical analyses}

Data were analysed using IBM SPSS Statistics. Birth order was analysed with respect to suckling stability, suckling preferences and growth performance with special attention given on the two delayed piglets. The following data analyses were carried out. Relation between birth order and suckling stability (for day 1 only) was analysed using simple descriptive statistics (means, standard deviations). The effect of birth order could not be assessed due to limited variability in the group of delayed piglets. The relationship between birth order and suckling preference, i.e. preferential teat(s), was graphically presented. The illustration shows where a specific piglet suckled on different days in lactation (anterior, middle, posterior), i.e. first suckling immediately after birth and later on $1^{\text {st }}, 15^{\text {th }}$ and $30^{\text {th }}$ day of lactation. The effect of birth order on growth performance (daily gain) was analysed using non-parametric test Independent-Samples Kruskal-Wallis Test with birth order group (early born, late born, delayed) included in the model as a fixed effect.

\section{RESULTS AND DISCUSSION}

\section{Suckling stability}

As expected, suckling order was unstable at the beginning of lactation (day 1) and varied greatly among piglets. It ranged from 0.00 to 1.00 with an average value of 0.24 (Fig. 1). In the middle and at the end of lactation (day 15 and 30), suckling stability increased to 0.98 and 1.00 , respectively. The values determined are consistent with the normal course of suckling order formation. As to the literature, the beginning of lactation is characterised by the wide suckling range when it is normal for piglets to suckle even all over the udder (e.g. see Skok and Škorjanc 2014). Yet, piglets choose their preferred suckling position already in the first days of lactation (until day 3 according to De Passillé et al., 1988) and reach the peak of the suckling stability somewhere in the middle of the second week of lactation; suckling order, despite fluctuations, then remain relatively stable till the end of lactation (Skok and Škorjanc, 2014). Our results further indicated a relation between the initial suckling stability (for the day 1) and birth order (Fig. 1); a trend of decreasing suckling stability with birth order can be observed $(0.33,0.24$ and 0.00 for early born, late born and delayed piglets, respectively). In two delayed piglets, which were of particular interest here, we recorded completely unstable suckling on the first day of lactation - a complete instability of suckling was additionally found only in two other piglets that turned out to be weaklings and have died during lactation. On the other hand, the delayed piglets, contrary to expectations, survived and grew relatively well during lactation. Later (on the $15^{\text {th }}$ and $30^{\text {th }}$ day of lactation, respectively), the delayed piglets, however, established a completely stable suckling order (1.00), comparable with the rest of the litter. These results are somehow in accordance with findings by Rosillon-Warnier and Paquay (1984), who reported no effect of birth order on the teat order formation, yet, they considered the suckling position only but not the suckling stability.

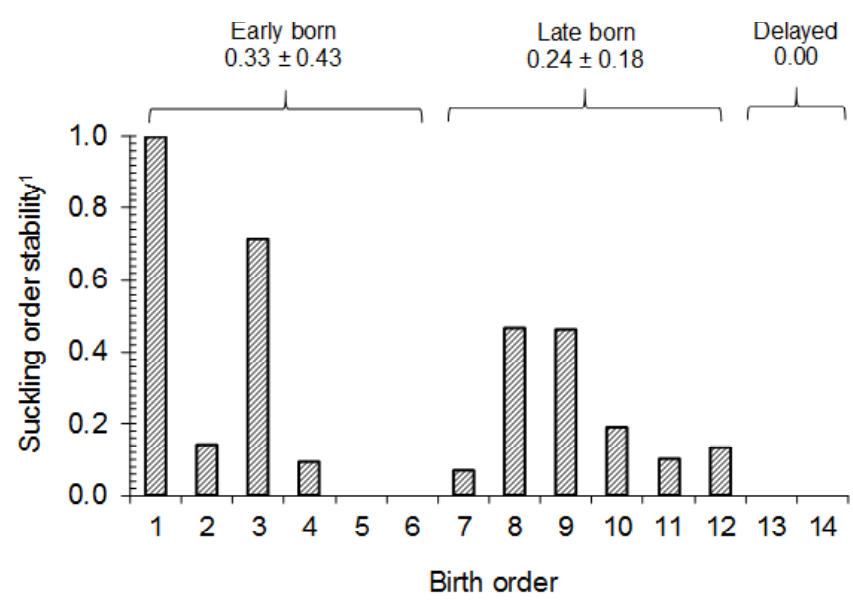

${ }^{1}$ Values are presented for day 1 of lactation only (average of 0.24 ) as for day 15 and 30 suckling order stability was 0.98 and 1.00 , respectively (no variability). The greater the value the more stable the suckling behaviour observed.

Figure 1: Suckling order stability and its relationship with birth order

\section{Preferential teats}

Figure 2 shows piglets' choice of teats (udder part anterior, medium, posterior) according to the birth order. Immediately after birth, posterior $(n=7)$ and medium teats $(n=5)$ have most often been chosen, which is in accordance with published results that new-born piglets grasp the nearest teats (Slengers et al., 2021), which is the case also in the wild boar, indicating this behaviour as an evolutionary adaptation (Fernandez-Llario and Mateos-Quesada, 2005). On the first day of the lactation, when the suckling order was still quite unstable, the piglets moved a lot across the udder and thus constantly changed the teats and suckling areas. Most of the piglets have chosen medium teats which also most likely has ancestral origin (see Skok and Gerken, 2016). After the stable suckling order was established (day 15 and 30), the earlyborn piglets mostly suckled in the anterior and medium area, while piglets born later more often suckled in posterior part (Fig. 2). Interestingly, the delayed $13^{\text {th }}$ and $14^{\text {th }}$ piglet deviated slightly from this general trend as they suckled preferentially on the $2^{\text {nd }}$ and $6^{\text {th }}$ teat pair, respectively. These results partially contradict to findings by Rosillon-Warnier and Paquay (1984) whose study showed some tendency of later born piglets to suckle more posteriorly while they did not prove any firm exclusivity toward front teats by piglets 


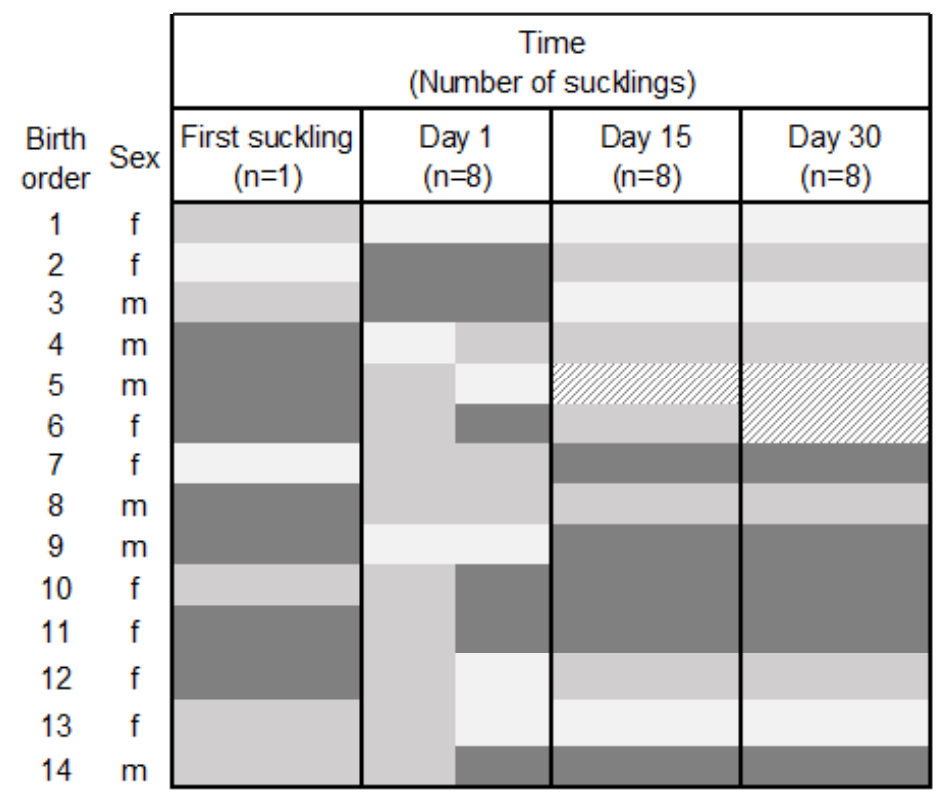

Figure 2: Preferential teats according to the birth order

that were born first. Furthermore, it has been reported that stillborn and posteriorly presented piglets were delivered after a significantly longer birth interval than live born and anteriorly suckling piglets (van Dijk et al., 2005).

\section{Survival and growth performance}

There was no stillborn piglet, but two died during lactation. Those two were of lower body weight $(1.74$ and $1.46 \mathrm{~kg}$, respectively) and had a completely unstable suckling order on day 1 ( $p_{\text {suck }}$ of 0.00$)$. These two piglets were born as $5^{\text {th }}$ and $6^{\text {th }}$ in a row - i.e., in the initial part of the birth sequence. Suckling stability was zero also for the last two piglets (born as $13^{\text {th }}$ and $14^{\text {th }}$ about 12 hours later than other littermates), but they had an average body weight (1.80 and $1.92 \mathrm{~kg}$, respectively) and survived.

Survival of piglets after such an extremely prolonged expulsion interval is rather unexpected as it normally significantly increases the chances of piglet death even in uncomplicated parturitions with a birth interval up to 4 hours (see van Dijk et al., 2005; Taverne and Van Der Weijden, 2008), which is considerably shorter than that in our case ( $\sim 12$ hours). Other studies also showed that birth order negatively affects prenatal mortality (Tuchscherer et al., 2000; Baxter et al., 2008; Pedersen et al., 2011; Rootwelt et al., 2012; Panzardi et al., 2013; Langendijk et al., 2018; Udomchanya et al., 2019), but does not have any effect on the postnatal mortality (Cabrera et al., 2012; Charneca et al., 2015). Therefore, under normal circumstances, such a long delay in birth, as reported here, should by all means result in prenatal mortality. However, we have not conducted any examination or acquired additional data concerning the delayed birth; therefore, we cannot explain this phenomenon.

Considering performance of piglets, we found a general trend of reducing body weight with the birth order especially for days 15 and 30, but also for day 1 (Fig. 3). Table 1 presents the effect of birth order groups (early born, late born, delayed) on growth performance. The results showed higher growth rate (daily gain) of the early born piglets compared to other two groups. Although the differences among birth order groups were quite large, they were not statistically significant, probably due to small sample size. Our results are in accordance with e.g. Friend and Cunningham (1966) and Hartsock and Graves (1976) who reported lower weight of last born piglets. However, there are several studies showing opposite results, i.e., positive correlation between birth order and body weight (Beaulieu et al., 2010; Charneca et al., 2013; Le Dividich et al., 2017). The reason for generally slower growth of late born piglets, could firstly be ascribed to initial difference in body weight, i.e. low birth weight of piglets correlates with lower post-natal growth rates (Cabrera et al., 201; Quiniou et al., 2002). Secondly, the late born piglets at least partially missed the period when the colostrum is the most energy rich with the highest concentrations of immunoglobulins. In our case, the delayed piglets missed literally a whole period of protein/immunoglobulin rich colostrum production, which lasts typically for 12 hours post partum unless whether, here, it was re-started after birth of the delayed piglets, which we are also not able to confirm. Further, the reason could also be the suckling latency (as reported by Cabrera et al., 2012), although our results showed that the time from birth to first suckling did not differ between birth order groups and was even shorter for the delayed piglets $(15,12$ and 8 minutes for early-born, late born and delayed piglets, respectively). This is in accordance with the study of Balzani et al. (2016) who reported that late born piglets found the teats faster than early born piglets. Another possible explanation is that the colostrum consumption also has a significant effect on muscle protein synthesis, increasing it 1.5-fold (Burrin et al., 1992). This is an important signal especially for protein synthesis in the myofibril compartment (Fiorotto et al., 2000). Perhaps this fact explains that piglets born with a longer delay consumed less colostrum, consequently had lower muscle protein synthesis, and in our study achieved lower body weight and daily gains during lactation. 
Table 1: The effect of birth order on the growth rate

\begin{tabular}{|c|c|c|c|c|c|c|c|}
\hline & \multicolumn{6}{|c|}{ Birth order group } & \multirow{3}{*}{$p$} \\
\hline & \multicolumn{2}{|c|}{ Early born $\left(1^{\text {st }}-6^{\text {th }}\right)$} & \multicolumn{2}{|c|}{ Late born $\left(7^{\text {th }}-12^{\text {th }}\right)$} & \multicolumn{2}{|c|}{ Delayed $\left(13^{\text {th }}-14^{\text {th }}\right)$} & \\
\hline & Mean \pm SD & $\mathrm{CV}, \%$ & Mean \pm SD & $\mathrm{CV}, \%$ & Mean \pm SD & $\mathrm{CV}, \%$ & \\
\hline Day 1 to 15 & $284 \pm 52$ & 18.2 & $202 \pm 42$ & 20.9 & $142 \pm 73$ & 51.4 & 0.201 \\
\hline Day 15 to 30 & $329 \pm 32$ & 9.6 & $253 \pm 26$ & 10.2 & $241 \pm 45$ & 18.6 & 0.174 \\
\hline Day 1 to 30 & $320 \pm 42$ & 13.1 & $236 \pm 34$ & 14.5 & $196 \pm 59$ & 30.2 & 0.201 \\
\hline
\end{tabular}

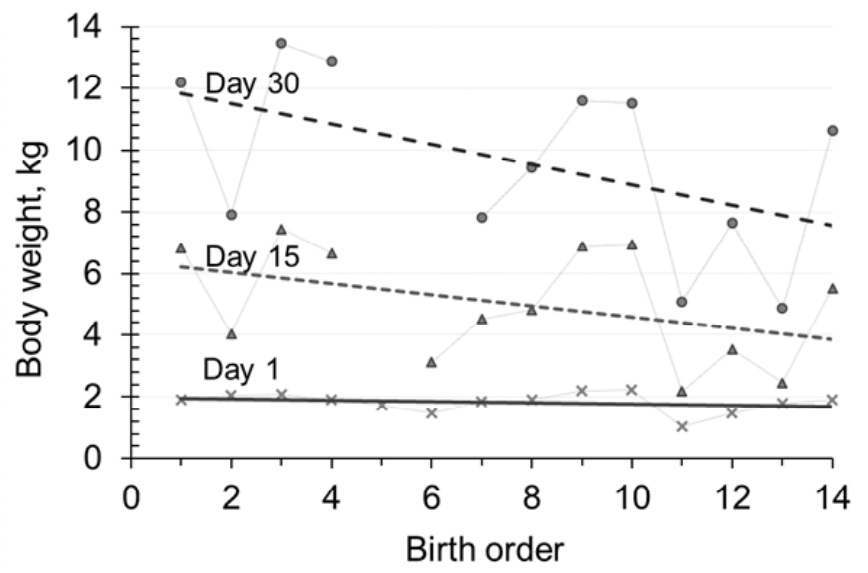

Figure 3: Reduction of body weight with birth order

\section{CONCLUSION}

Although no firm conclusion can be drawn from the present case study, the reported abnormal delay in birth of

two piglets that unexpectedly survived provide exceptional insight on the association between birth order, suckling order (position), suckling stability, and growth performance. The results confirmed past findings and showed that even in the case of an extraordinarily long delay in birth, there is no clear association neither with the suckling order and its stability nor with the birth/body weight and daily weight gain. Ultimately, the survival of piglets after that long delay in birth itself represents an extraordinary phenomenon that we cannot explain.

\section{REFERENCES}

1. Ayliffe, T. R., Noakes, D. E., \& Silva, J. R. (1984). The effect of experimental induced hypocalcaemia on uterine activity in the sow during parturition and postpartum, Theriogenology, 21, 803-822 DOI: https://doi. org/10.1016/0093-691X(84)90024-4

2. Beaulieu, A. D., Aalhus, J. L., Williams, N. H., \& Patience, J. F. (2010). Impact of piglet birth weight, birth order, and litter size on subsequent growth performance, carcass quality, muscle composition, and eating quality of pork. Journal of Animal Science, 88, 2767-2778. DOI: https:// doi.org/10.2527/jas.2009-2222

3. P. Bories, Chronopart de la truie en élevage: e Balzani, A., Cordell, H. J., \& Edwards, S. A. (2016). Relationship of sow udder morphology with piglet suckling behaviour and teat access. Theriogenology, 86(8), 1913-1920. DOI: https://doi.org/10.1016/j.theriogenology.2016.06.007

4. Baxter, E. M., Jarvis, S., D’Eath, R.B., Ross, D.W., Robson, S.K., Farish, M., Nevison, I.M., Lawrence, A.B., \& Edwards, S.A. (2008). Investigating the behavioural and physiological indicators of neonatal survival in pigs. Theriogenology, 69(6), 773-783. DOI: https://doi. org/10.1016/j.theriogenology.2007.12.007.

5. Bland, I. M., Rooke, J. A., Bland, V. C., Sinclair, A. G., \& Edwards, S. A. (2003). Appearance of immunoglobulin $\mathrm{G}$ in the plasma of piglets following intake of colostrum, with or without a delay in sucking. Animal Science, 77(2), 277-286. DOI: https://doi.org/10.1017/ S1357729800059014

6. Blim, S., Schupp, D., \& Bostedt, H. (2020). Das Schwein in der peripartalen Periode: klinische, ethologische, endokrinologische und stoffwechselbezogene Aspekte. Tierärztliche Praxis Ausgabe G: Großtiere / Nutztiere, 48, 414-421. DOI: 10.1055/a-1274-9057

7. Burrin, D. G., Shulman, R. J., Reeds, P. J., Davis, T. A., \& Gravitt, K. R. (1992). Porcine colostrum and milk stimulate visceral organ and skeletal muscle protein synthesis in neonatal piglets. The Journal of Nutrition, 122(6), 1205-1213. DOI: https://doi.org/10.1093/ jn/122.6.1205

8. Cabrera, R. A., Lin, X., Campbell, J. M., Moeser, A. J., \& Odle, J. (2012). Influence of birth order, birth weight, colostrum and serum immunoglobulin $\mathrm{G}$ on neonatal piglet survival. Journal of Animal Science and Biotechnology, 3(1), 42. DOI: https://doi. org/10.1186/2049-1891-3-42

9. Canario, L., Roy, N., Gruand, J., \& Bidanel, J. P. (2006). Genetic variation of farrowing kinetics traits and their relationships with litter size and perinatal mortality in French Large White sows. Journal of Animal Science, 84,(5), 1053-1058, DOI: https://doi. org/10.2527/2006.8451053x

10. Charneca, R., Vila-Viçosa, M. J., Infante, P., Nunes, J., \& Le Dividich, J. (2015). Colostrum production of Alentejano and Large-White $\times$ Landrace sows: consumption, passive immunity and mortality of piglets. Spanish Journal of Agricultural Research, 13(4), e0611. DOI: https://doi. org/10.5424/sjar/2015134-7537

11. Charneca, R., Freitas, A., Nunes, J., \& Le Dividich, J. (2013). Relationship between birth order and birth weight of the pig. Proceedings of the $64^{\text {th }}$ Annual Meeting of the EAAP, p 394.

12. Fernandez-Llario, P., \& Mateos-Quesada, P. (2005). Udder preference in wild boar piglets. Acta Ethologica, 8(1), 51-55. DOI: https://doi.org/10.1007/s10211-0050109-5

13. Fiorotto, M. L., Davis, T. A. Reeds, P. J., \& Burrin, D. 
G. (2000). Nonnutritive factors in colostrum enhance myofibrillar protein synthesis in the newborn pig. Pediatric Research, 48, 511-517.

14. Fraser, D., \& Morley Jones, R. (2009). The 'teat order' of suckling pigs: I. Relation to birth weight and subsequent growth. Journal of Agricultural Science, 84(3), 387-391. DOI: https://doi.org/10.2527/jas1977.442320x

15. Friend, D. W., \& Cunningham, H. M. (1966). Piglet birthweights and the order of farrowing. Canadian Journal of Comparative Medicine and Veterinary Science, 30(7), 179-182.

16. Hartsock, T. G., \& Graves, H. B. (1976). Neonatal behavior and nutritional-related mortality in domestic swine. Journal of Animal Science, 42, 235-241. DOI: https://doi.org/10.2527/jas1976.421235x

17. Herpin, P., Le Dividich, J., Claude Hulin, J., Fillaut, M., De Marco, F., \& Bertin, R. (1996). Effects of the level of asphyxia during delivery on viability at birth and early postnatal vitality of newborn pigs. Journal of Animal Science, 74(9), 2067-2075. DOI: https://doi. org/10.2527/1996.7492067x

18. Herpin, P., Damon, M., \& le Dividich, J. (2002). Development of thermoregulation and neonatal survival in pigs. Livestock Production Science, 78(1), 25-45. https:// doi.org/10.1016/S0301-6226(02)00183-5

19. Kim, S. W., Hurley, W. L., Hant, I. K., \& Easter, R. A. (2000). Growth of nursing pigs related to the characteristics of nursed mammary glands. Journal of Animal Science, 78, 1313-1318. DOI: https://doi. org/10.2527/2000.7851313x

20. Langendijk, P., Fleuren, M., Van Hees, H., \& Van Kempen, T. (2018). The course of parturition affects piglet condition at birth and survival and growth through the nursery phase. Animals, 8(5), 60. DOI: https://doi. org/10.3390/ani8050060

21. Le Dividich, J., Rooke, J. A., \& Herpin, P. (2005). Nutritional and immunological importance of colostrum for the new-born pig. Journal of Agricultural Science, 143(06), 469-485. DOI: https://doi.org/10.1017/ S0021859605005642

22. Nagel, C., Aurich, C., \& Aurich, J. (2019). Stress effects on the regulation of parturition in different domestic animals species. Animal Reproduction Science, 207, 153-161. DOI: https://doi.org/10.1016/j.anireprosci.2019.04.011

23. Nowak, R., Porter, R. H., Lévy, F., Orgeur, P., \& Schaal, B. (2000). Role of mother-young interactions in the survival of offspring in domestic mammals. Reviews of Reproduction, 5, 153-163.

24. Ogawa, S., Tsukahara, T., Tsuruta, T., Nishibayashi, R., Okutani, M., Nakatani, M., Higashide, K., Iida, S., Nakanishi, N., Ushida, K., \& Inoue, R. (2014). Evaluation of secretion volume and immunoglobulin A and $\mathrm{G}$ concentrations in sow colostrum from anterior to posterior teats. Animal Science Journal, 85(6), 678-682. DOI: https://doi.org/10.1111/asj.12211

25. Oliviero, C., Heinonen, M., Valros, A., \& Peltoniemi, O. (2010). Environmental and sow-related factors affecting the duration of farrowing. Animal Reproduction Science, 119(1-2), 85-91. DOI: https://doi.org/10.1016/j. anireprosci.2009.12.009
26. Panzardi, A., Bernardi, M. L., Mellagi, A. P., Bierhals, T., Bortolozzo, F. P., \& Wentz, I. (2013). Newborn piglet traits associated with survival and growth performance until weaning. Preventive Veterinary Medicine, 110(2), 206-213. DOI: https://doi.org/10.1016/j. prevetmed.2012.11.016

27. Pedersen, L. J., Berg, P., Jørgensen, G., \& Andersen, I. L. (2011). Neonatal piglet traits of importance for survival in crates and indoor pens. Journal of Animal Science, 89(4), 1207-1218. DOI: https://doi.org/10.2527/ jas.2010-3248

28. Peltoniemi, O., \& Oliviero, C. (2011). Factors affecting physiology and endocrinology of farrowing. In F. Akin (Ed.), Basic and clinical endocrinology up-to-date. InTech.

29. Quiniou, N., Dagorn, J., \& Gaudré, D. (2002). Variation of piglets' birth weight and consequences on subsequent performance. Livestock Production Science, 78(1), 63-70. DOI: https://doi.org/10.1016/S0301-6226(02)00181-1

30. Randall, G. C. (1972). Observations on parturition in the sow. I. Factors associated with the delivery of the piglets and their subsequent behaviour. Veterinary Records, 90(7), 178-82. DOI: https://doi.org/10.1136/vr.90.7.178

31. Rooke, J. A., \& Bland, I. M. (2002). The acquisition of passive immunity in the new-born piglet. Livestock Production Science, 78, 13-23. DOI: https://doi. org/10.1016/S0301-6226(02)00182-3

32. Rootwelt, V., Reksen, O., Farstad, W., \& Framstad, T. (2012). Blood variables and body weight gain on the first day of life in crossbred pigs and importance for survival. Journal of Animal Science, 90(4), 1134-1141. DOI: https://doi.org/10.2527/jas.2011-4435

33. Rosillon-Warnier, A., \& Paquay, R. (1984). Development and consequences of teat-order in piglets. Applied Animal Behaviour Science, 13(1-2), 47-58. DOI: https:// doi.org/10.1016/0168-1591(84)90051-0

34. Slegers, Y., Oolbekkink, Y., Roelofs, S., Van der Staay, F. J., \& Nordquist, R. E. (2021). Effects of birth order on performance and affective state of pigs. Frontiers in Animal Science, 2, 669692. DOI: https://doi.org/10.3389/ fanim.2021.669692

35. Skok, J., \& Gerken, M. (2016). Suckling strategies in the pig: The Göttingen minipig as a model. Livestock Science, 184, 78-84. DOI: https://doi.org/10.1016/j. livsci.2015.12.012

36. Skok, J., \& Škorjanc, D. (2013). Formation of teat order and estimation of piglets' distribution along the mammary complex using mid-domain effect (MDE) model. Applied Animal Behaviour Science, 144(1-2), 39-45. DOI: https:// doi.org/10.1016/j.applanim.2012.11.014

37. Skok, J., \& Škorjanc, D. (2014). Group suckling cohesion as a prelude to the formation of teat order in piglets. Applied Animal Behaviour Science, 154, 15-21. DOI: https://doi.org/10.1016/j.applanim.2014.02.003

38. Taverne, M. A. M., \& Van Der Weijden, G. C. (2008). Parturition in domestic animals: targets for future research. Reproduction in Domestic Animals, 43, 36-42. DOI: https://doi.org/10.1111/j.1439-0531.2008.01219.x

39. Tuchscherer, M., Puppe, B., Tuchscherer, A., \& Tiemann, U. (2000). Early identification of neonates at risk: Traits of 
newborn piglets with respect to survival. Theriogenology, 54(3), 371-388. DOI: https://doi.org/10.1016/S0093$691 X(00) 00355-1$

40. Udomchanya, J., Suwannutsiri, A., Sripantabut, K., Pruchayakul, P., Juthamanee, P., Nuntapaitoon, M., \& Tummaruk, P. (2019). Association between the incidence of stillbirths and expulsion interval, piglet birth weight, litter size and carbetocin administration in hyper-prolific sows. Livestock Science, 227, 128-134. DOI: https://doi. org/10.1016/j.livsci.2019.07.013

41. Van Dijk, A. J., Van Rens, B. T. T. M., Van der Lende, T., \& Taverne, M. A. M. (2005). Factors affecting duration of the expulsive stage of parturition and piglet birth intervals in sows with uncomplicated, spontaneous farrowings. Theriogenology, 64(7), 1573-1590. DOI: https://doi.org/10.1016/j.theriogenology.2005.03.017 


\section{Zaporedje rojstva, sesno obnašanje in rastnost pujskov: Študija primera ekstremne zakasnitve rojstva dveh preživelih pujskov}

\section{IZVLEČEK}

Pri prašičih je zakasnelo rojstvo povezano z višjo stopnjo umrljivosti, pri čemer ekstremna zakasnitev praviloma pomeni prenatalno smrt. V članku je predstavljena študija primera izredne zakasnitve rojstva dveh preživelih pujskov (zakasnela pujska), ki sta se rodila 15 ur po začetku, oziroma 12 ur po tem, ko je bil rojen zadnji pujsek glavnega dela prasitve. Preostanek opazovanega gnezda $(n=12)$ smo razdelili na dve podskupini, zgodnje rojeni ( $n=6$, rojeni v prvih 80 minutah) in pozno rojeni pujski ( $n=6$, rojeni v naslednjih 80 minutah od začetka prasitve). Sesno obnašanje, preživetje in rastnost pujskov smo preučevali v povezavi Z rojstnim zaporedjem, pri čemer smo posebno pozornost namenili zakasnelima pujskoma. V splošnem se je sesna stabilnost Z naraščajočim zaporedjem rojstva zmanjševala; zakasnela pujska sta imela popolnoma nestabilno sesanje. Za prvo sesanje so pujski večinoma izbirali zadnje seske, kasneje, ko je bil sesni red že vzpostavljen, pa so zgodaj rojeni pujski najpogosteje sesali na sprednji, pozno rojeni pa na zadnji polovici vimena. Zakasnela pujska sta takoj po rojstvu izbrala seske na srednjem delu vimena, kasneje pa sta preferenčno sesala na različnih delih (na 2. in 6. sesnem paru). Rastnost zakasnelih pujskov je bila nižja, čeprav neznačilno (kar je verjetno posledica majhnega vzorca) v primerjavi s pozno in predvsem zgodnje rojenimi pujski. Kljub izjemni zakasnitvi rojstva nismo ugotovili jasne povezave s sesnim redom in njegovo stabilnostjo, porodno oziroma telesno maso in dnevnim prirastom. Preživetje pujskov, rojenih s tolikšno zakasnitvijo, je samo po sebi izjemen pojav, ki pa ga v kontekstu dane raziskave ne moremo pojasniti.

Ključne besede: zaporedje ob rojstvu, sesno obnašanje, rastnost, zakasnitev pri rojstvu 